\title{
DAPATKAH TEORI FRAUD TRIANGLE MENJELASKAN KECURANGAN \\ DALAM LAPORAN KEUANGAN?
}

\author{
Dwi Ratmono \\ Yuvita Avrie Diany \\ Agus Purwanto \\ Departemen Akuntansi Fakultas Ekonomika dan Bisnis Universitas Diponegoro
}

\begin{abstract}
The objective of this study is to test the ability of fraud triangle theory to explain financial statement fraud phenomena. To achieve the objective, this research examines factors which affect financial statement fraud. Based on fraud triangle theory, there are three variables hypothesized affect fraud which are pressure, opportunity and rationalization. This study uses data of 27 companies which did financial statement fraud and 27 other companies as pair matched sample. Data collected from annual report published by website Indonesian Stock Exchange (IDX). Data then analyzed using logistic regression analysis. The result of this study shows significant positive relation between pressure and opportunity with financial statement fraud. Rationalization is not supported as determinant of financial statement fraud. This study provides partial support for fraud triangle theory in explaining financial statement fraud phenomena.
\end{abstract}

Keywords: financial statement fraud, pressure, opportunity, rationalization,

\section{PENDAHULUAN}

Laporan keuangan merupakan salah satu bentuk alat komunikasi oleh manajer puncak kepada bawahannya serta kepada pihak luar perusahaan untuk menginformasikan aktivitas perusahaan selama periode waktu tertentu. Pelaporan keuangan ini ditujukan kepada para pihak yang terkait sebagai bentuk pertanggungjawaban perusahaan atas aliran dana investasi dan kredit yang masuk ke perusahaan, serta untuk menjaring adanya investor baru yang tertarik untuk menanamkan modal. Tertuang dalam Statement of Financial Accounting Concept
(SFAC) No.1 mengenai tujuan dari pelaporan keuangan, salah satunya adalah menyediakan informasi yang berguna untuk para investor dan kreditor yang sudah ada maupun para investor dan kreditor potensial dalam membuat suatu keputusan yang rasional mengenai investasi, kredit, serta keputusan lain yang sejenis. Menyadari pentingnya kandungan informasi dalam laporan keuangan menjadikan para manajer termotivasi untuk meningkatkan kinerja perusahaan dengan begitu eksistensi perusahaan akan tetap terjaga. Namun terdapat beberapa kasus di mana manajer gagal dalam mencapai tujuan kinerjanya 
sehingga informasi yang akan tampil dalam laporan keuangan tidak akan memuaskan. terkadang manajemen rela melakukan kecurangan supaya informasi dalam laporan keuangan terlihat baik. sebagai upaya dalam mencegah perbuatan tersebut maka menjadi tugas bagi auditor untuk mendeteksi adanya kecurangan.

Standar Auditing Seksi 316 (PSA no. 70) (IAPI,2013) menyatakan bahwa auditor tidak dapat memperoleh keyakinan absolut namun auditor harus dapat memperoleh keyakinan memadai bahwa salah saji material dalam laporan keuangan dapat terdeteksi, termasuk salah saji material sebagai akibat dari kecurangan. Audit harus secara khusus menaksir risiko salah saji material dalam laporan keuangan sebagai akibat dari kecurangan dan harus mempertimbangkan taksiran risiko ini dalam mendesain prosedur audit yang akan dilaksanakan. Saat melakukan penaksiran ini, auditor harus mempertimbangkan faktor risiko kecurangan yang berdasarkan pada teori fraud triangle oleh Cressey (1953). Cressey (1953) menyatakan jika kecurangan laporan keuangan disebabkan oleh tiga kondisi, yaitu tekanan (pressure), kesempatan (opportunity), dan rasionalisasi (rationalization) yang sering disebut dengan fraud triangle. Teori ini telah diadopsi dalam standar auditing dan dianggap sebagai salah literatur utama dalam menjelaskan fenomena kecurangan laporan keuangan.
Meskipun demikian, kemampuan teori tersebut dalam menjelaskan fenomena kecurangan laporan keuangan belum banyak terbukti secara empiris.

Skousen et al. (2009) telah menguji secara empiris kemampuan teori fraud triangle tersebut dalam menjelaskan terjadi kecurangan laporan keuangan. Namun, dalam konteks Indonesia, temuan tersebut belum tentu dapat digeneralisir. Oleh karena itu, masih menjadi pertanyaan penelitian tentang generalisasi temuan penelitian terdahulu tersebut. Hal ini karena kondisi sosial, politis, budaya, dan ekonomi serta faktor regulasi tata kelola perusahaan (corporate governance) yang berbeda. Perbedaan konteks institusional yaitu Indonesia termasuk kluster negara-negara code law dengan tingkat perlindungan investor yang lemah dan sistem tata kelola two-tiers boars systems (Leuz dkk., 2003; Djankov dkk, 2008) mungkin membatasi generalisasi temuan terdahulu ke dalam konteks Indonesia. Penelitian ini berkontribusi dalam memberikan bukti empiris tentang kemampuan teori fraud triangle dalam menjelaskan fenomena kecurangan laporan keuangan di Indonesia.

\section{TELAAH TEORITIS DAN PENGEMBANGAN HIPOTESIS}

Cressey (1953) menyatakan sebuah teori yang dikenal sebagai fraud triangle, yaitu bahwa terdapat tiga kondisi yang 
selalu hadir saat terjadi kecurangan laporan keuangan. Ketiga kondisi tersebut adalah tekanan (pressure), kesempatan (opportunity), dan rasionalisasi (rationalization) yang kemudian dikenal dengan istilah fraud triangle. Tekanan adalah dorongan yang menyebabkan seseorang melakukan kecurangan. Pada umumnya yang mendorong terjadinya kecurangan adalah kebutuhan finansial tapi banyak juga yang hanya terdorong oleh keserakahan. Tekanan situasional berpotensi muncul karena adanya kewajiban keuangan yang melebihi batas kemampuan yang harus diselesaikan manajemen. Kesempatan adalah peluang yang memungkinkan kecurangan terjadi. Biasanya disebabkan karena pengendalian internal suatu organisasi yang lemah, kurangnya pengawasan, atau penyalahgunaan wewenang (Gagola, 2011). Rasionalisasi menjadi elemen penting dalam terjadinya kecurangan karena pelaku mencari pembenaran atas tindakannya. Pembenaran ini bisa terjadi saat pelaku ingin membahagiakan keluarga dan orang-orang yang dicintainya, pelaku merasa berhak mendapatkan sesuatu yang lebih (posisi, gaji, promosi) karena telah lama mengabdi pada perusahaan, atau pelaku mengambil sebagian keuntungan karena perusahaan telah menghasilkan keuntungan yang besar.

$$
\text { Hall (dalam Rustendi, 2009) }
$$
mengemukakan bahwa mereka yang terlibat dalam tindak kecurangan didorong oleh interaksi antara kekuatan dalam kepribadian individu dengan lingkungan eksternal. Dalam hal ini risiko terjadinya kecurangan cenderung akan semakin besar apabila seseorang berada dalam tekanan situasional, ada kesempatan, dan yang bersangkutan memiliki integritas yang rendah. Di bawah ini disajikan skema interaksi di antara faktor-faktor yang dapat menimbulkan kecurangan.

\section{Gambar 1.1}

Faktor Penyebab Kecurangan

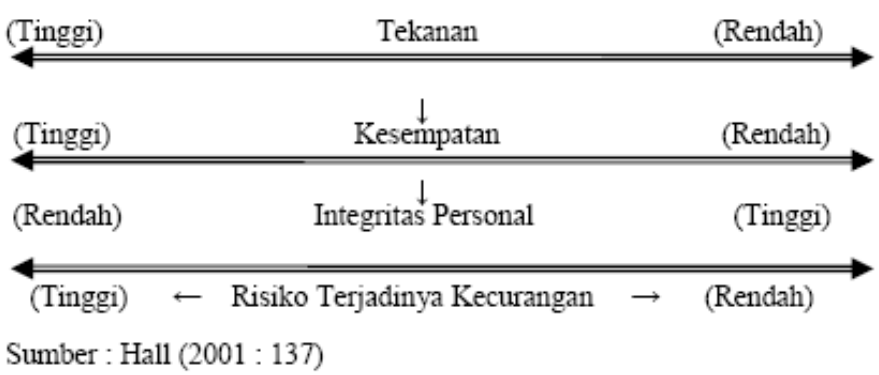



Salah satu teori yang melandasi penelitian ini adalah teori agensi (agency theory). Jensen dan Meckling (1976) menyatakan bahwa teori agensi dapat menjelaskan hubungan yang terjadi antara pemilik dan pemegang saham (principal) dengan manajemen (agent). Dalam sebuah perusahaan, manajer berperan sebagai agent yang secara moral bertanggung jawab untuk mengoptimalkan keuntungan para pemilik (principal), namun di sisi lain manajer juga memiliki kepentingan memaksimumkan kesejahteraan mereka. Perbedaan kepentingan yang terjadi pada diri manajer inilah yang memicu adanya agency problem sehingga pelanggaran seperti memanipulasi laporan keuangan dapat terjadi.

Berikut disajikan gambar kerangka pemikiran yang menunjukkan hubungan antarvariabel:

\section{Gambar 1.2}

\section{Kerangka Pemikiran}

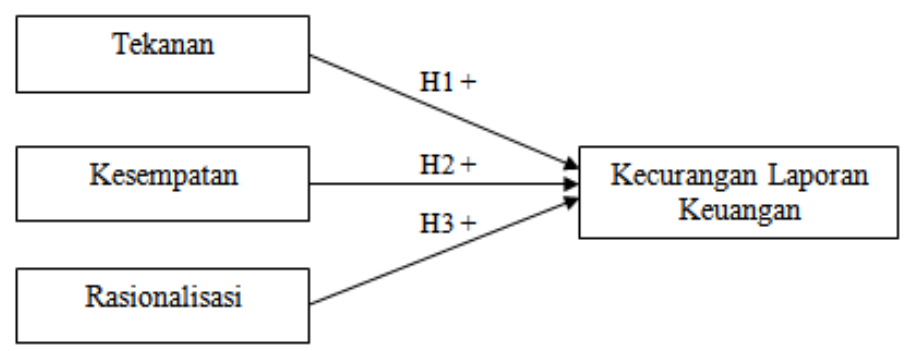

\section{Tekanan}

Salah satu kondisi yang selalu hadir saat terjadi kecurangan laporan keuangan adalah tekanan (Cressey, 1953). Tekanan dapat terjadi saat manajemen sedang membutuhkan uang untuk memenuhi kebutuhan pribadinya misalnya tekanan untuk biaya pengobatan, tekanan dari keluarga yang menuntut keberhasilan secara ekonomi, serta pola hidup mewah (Rustendi, 2009). Bonus akhir tahun akan menjadi sumber penghasilan yang besar sehingga manajemen akan sengaja untuk memanipulasi labanya demi mendapatkan pendapatan. Tekanan juga bisa timbul saat kinerja perusahaan berada pada titik di bawah rata-rata kinerja industri (Skousen et al., 2009). Kondisi seperti ini menunjukkan bahwa perusahaan sedang dalam kondisi tidak stabil karena tidak mampu memaksimalkan aset yang dimiliki serta tidak dapat menggunakan sumber dana investasi secara efisien. Kinerja perusahaan yang buruk akan berdampak pada kurangnya aliran dana yang masuk ke dalam 
perusahaan, terutama dana yang didapatkan dari para investor potensial. Namun semakin banyak aliran dana yang masuk dalam perusahaan tentunya semakin banyak pula beban yang ditanggung manajemen untuk melunasi hutang perusahaan. Untuk menguji hubungan antara tekanan dengan kecurangan laporan keuangan, maka penelitian ini akan menguji H1 yang dirumuskan sebagai berikut:

H1. Tekanan berpengaruh positif terhadap terjadinya kecurangan laporan keuangan.

\section{Kesempatan}

Kesempatan akan timbul saat sistem pengendalian internal perusahaan lemah (Gagola, 2011). Perusahaan dengan pengendalian internal yang lemah akan memiliki banyak celah yang menjadikan kesempatan bagi manajemen untuk memanipulasi transaksi. Adanya informasi asimetri yang terjadi antara pemilik perusahaan selaku prinsipal dan manajemen selaku agen juga bisa menjadi sebuah kesempatan untuk melakukan kecurangan laporan keuangan. Informasi asimetri dialami oleh prinsipal saat seluruh tindakan yang dilakukan manajemen tidak bisa diawasi secara langsung. Menyadari peluang yang timbul dari kondisi ini memberikan peluang bagi manajemen untuk melakukan kecurangan laporan keuangan. Konsep Good Corporate Governance (GCG) semakin banyak dikemukakan oleh para praktisi bisnis sebagai salah satu alat untuk mencegah terjadinya kasus kecurangan. Salah satu komponen yang berperan penting dalam proses penerapan tata kelola perusahaan yang baik adalah komite audit. Peranan komite audit dalam menjamin kualitas pelaporan keuangan perusahaan telah menjadi sorotan sejak terjadi skandal akuntansi yang menjadi perhatian publik (Pamudji dan Trihartati, n.d.). Untuk menguji hubungan antara kesempatan dengan kecurangan laporan keuangan, maka penelitian ini akan menguji $\mathrm{H} 2$ yang dirumuskan sebagai berikut:

H2. Kesempatan berpengaruh positif terhadap terjadinya kecurangan laporan keuangan.

\section{Rasionalisasi}

Rasionalisasi lebih sering dihubungkan dengan sikap dan karakter seseorang yang membenarkan nilai-nilai etis yang sebenarnya tidak baik (Rustendi, 2009). Rendahnya integritas yang dimiliki seseorang menimbulkan pola pikir di mana orang tersebut merasa dirinya benar saat melakukan kecurangan, sebagai contoh manajemen membenarkan untuk melakukan praktek manajemen laba. Penyimpangan yang dilakukan manajemen juga disebut dengan moral hazard problem. Moeller (dalam Rustendi, 2009) menyatakan bahwa banyaknya praktik kecurangan yang banyak 
terjadi menjadi salah satu pemicu manajemen untuk melakukan hal yang sama seperti perusahaan lain sehingga manajemen menganggap bahwa kecurangan adalah suatu hal yang biasa dilakukan. Untuk menguji hubungan antara rasionalisasi dengan kecurangan laporan keuangan, maka penelitian ini akan menguji $\mathrm{H} 3$ yang dirumuskan sebagai berikut:

\section{H3. Rasionalisasi berpengaruh positif} terhadap kecurangan laporan keuangan.

\section{METODE PENELITIAN}

\section{Variabel penelitian}

Variabel dependen dalam penelitian ini adalah kecurangan laporan keuangan. Pengukuran kecurangan laporan keuangan menggunakan dummy, dimana 1 untuk menunjukkan perusahaan yang melakukan kecurangan laporan keuangan, dan 0 jika sebaliknya. Variabel independen yang digunakan dalam penelitian ini adalah tekanan, kesempatan, dan rasionalisasi. Karena variabel tersebut sulit untuk diukur secara langsung maka dibuatlah proksi atas tiap

variabel.

Tabel 1.1

Proksi Variabel

\begin{tabular}{|c|c|c|c|c|c|c|c|c|}
\hline \multirow{3}{*}{$\begin{array}{l}\text { Variabel } \\
\text { Tekanan }\end{array}$} & \multicolumn{8}{|c|}{ Proksi } \\
\hline & GPM & NPM & SCHANGE & ACHANGE & CATA & SALAR & SALTA & INVSAL \\
\hline & LOSS & NCFO & HIGHGR & LEV & FREEC & OSHIP & OWN & ROA \\
\hline Kesempatan & RECEIV & INVENT & ACSIZE & ACINDP & ACMEET & ACEXP & TURN & \\
\hline Rasionalisasi & AUDCHANGE & AUDREPORT & & & & & & \\
\hline
\end{tabular}

\section{Tekanan}

Loebbecke et al. dan Bell et al. (dalam Skousen et al., 2009) mengindikasikan bahwa saat perusahaan sedang dalam masa pertumbuhan di bawah rata-rata industri, manajemen bisa saja memanipulasi laporan keuangan untuk meningkatkan performa perusahaan. Kondisi perusahaan yang tidak stabil akan menimbulkan tekanan bagi manajemen karena kinerja perusahaan terlihat menurun di mata publik sehingga akan menghambat aliran dana investasi di tahun mendatang.
Proksi yang digunakan untuk stabilitas keuangan adalah gross profit margin (GPM), net profit margin (NPM), sales change (SCHANGE), asset change (ACHANGE).

Pada saat arus kas operasi negatif terjadi berulang-ulang saat melaporkan earning growth juga berhubungan dengan stabilitas keuangan (Skousen et al., 2009). Arus kas operasi negatif menandakan bahwa perusahaan tidak mampu menghasilkan kas dari aktivitas utama perusahaan. Kondisi 
seperti ini akan berdampak buruk pada perusahaan karena arus kas biasanya digunakan oleh investor dalam menganalisis mengenai kinerja perusahaan masa depan. Albrecht (dalam Skousen et al., 2009) pada penelitian sebelumnya menggunakan proksi rasio arus kas operasi terhadap aset (CATA) untuk mengukur stabilitas keuangan perusahaan yang memiliki hubungan negatif dengan kecurangan laporan keuangan.

Albrecth (dalam Gagola, 2011) menyatakan bahwa kecurangan bisa dilakukan dengan mencatat adanya penjualan fiktif. Adanya tambahan saldo dari penjualan fiktif tersebut maka saldo piutang dagang akan meningkat sehingga pendapatan perusahaan seolah-olah akan bertambah pula. Berdasarkan penelitian yang dilakukan oleh Gagola (2011) proksi sales to account receivable (SALAR) berhubungan positif dengan kecurangan laporan keuangan.

Perusahaan dengan kemampuan manajemen yang baik dalam menggunakan aset akan tetap survive dan mempunyai keunggulan kompetitif. Hal ini dikuatkan oleh hasil penelitian Persons (dalam Gagola, 2011) bahwa ketidakmampuan dalam penggunaan aset perusahaan memberikan motivasi bagi manajer untuk terlibat dalam kecurangan pelaporan keuangan. Kemampuan penggunaan aset secara baik mengindikasikan bahwa perusahaan mampu menghasilkan volume usaha tertentu untuk ukuran investasi sebesar total aktivanya dimana aspek ini diukur dengan proksi sales to total asset (SALTA) yang memiliki hubungan negatif dengan kecurangan laporan keuangan.

Persons (dalam Gagola, 2011) menunjukkan tindakan manajemen yang dapat memanipulasi akun persediaan misalnya perusahaan memilih untuk tidak mencatat jumlah yang tepat dari nilai persediaan yang sudah usang. Persediaan usang membuat jumlah barang yang tersedia untuk dijual akan menurun sehingga perusahaan tidak bisa mendapatkan laba secara maksimal dari kegiatan produksinya. Mengacu pada penelitian Gagola (2011) yang menggunakan proksi inventory to total asset (INVSAL) dalam stabilitas keuangan yang memiliki hubungan positif terhadap kecurangan laporan keuangan.

Hayn (dalam Lou dan Wang, 2009) menunjukkan bahwa tingkat cross-sectional pengembalian laba (atau harga) perusahaan yang dilaporkan mengalami kerugian jauh lebih lemah dibandingkan perusahaan yang melaporkan keuntungan. Adanya kerugian dari aktivitas utama perusahaan menandakan bahwa perusahaan tidak bisa memaksimalkan penjualannya sehingga para investor tidak akan menerima dividen pada tahun tersebut. Mengacu pada penelitian sebelumnya oleh Lou dan Wang (2009) bahwa perusahaan yang melaporkan adanya 
kerugian (LOSS) akan berpengaruh positif terhadap kecurangan laporan keuangan.

Skousen et al. (2009) menyatakan bawa ketidakmampuan untuk menghasilkan arus kas positif dalam pertumbuhan laba yang dilaporkan akan berkaitan dengan stabilitas keuangan. Penelitian yang sama juga dilakukan oleh Lou dan Wang (2009) bahwa ada hubungan positif yang terjadi antara arus kas operasi negatif dengan kecurangan laporan keuangan. Arus kas negatif akan berdampak pada penilaian investor karena arus kas dapat digunakan untuk meramalkan kinerja perusahaan di masa depan. Arus kas biasanya juga digunakan sebagai pembanding kinerja antar perusahaan. Jika perusahaan mengalami arus kas operasi negatif maka perusahaan tersebut sedang dalam kondisi tidak stabil dan menimbulkan suatu tekanan bagi manajemen. Berdasarkan uraian tersebut maka proksi arus kas operasi negatif berhubungan positif (NCFO) dengan kecurangan laporan keuangan.

Bell dan Carcello (dalam Lou dan Wang, 2009) membuktikan bahwa pertumbuhan perusahaan secara cepat dan drastis merupakan faktor risiko signifikan atas kemungkinan kecurangan pelaporan. Tingkat pertumbuhan perusahaan secara drastis biasanya dilakukan dengan praktek manajemen laba dalam bentuk taking bath dimana manajemen menjadikan laba perusahaan meningkat secara drastis dari periode sebelumnya. Untuk mengetahui tingkat pertumbuhan yang ekstrim, penelitian ini menggunakan pengukuran Krishnan (dalam Lou dan Wang, 2009) dengan proksi pertumbuhan aset perusahaan berbanding pertumbuhan aset industri (HIGHGR) yang memiliki hubungan positif dengan kecurangan laporan keuangan.

Kemampuan untuk mendapatkan pinjaman dari luar perusahaan serta kemampuan untuk membayar pinjaman tersebut dianggap sebagai tekanan yang bersumber dari faktor eksternal. Vermeer serta Press dan Weintrop (dalam Skousen et al., 2009) melaporkan bahwa saat dihadapi dengan pelunasan pinjaman maka manajer kemungkinan melakukan diskresionari akrual. Manajer dapat merasa tertekan sebagai dampak dari kebutuhan untuk menghasilkan tambahan pinjaman atau pembiayaan modal supaya tetap kompetitif, misalnya dengan adanya sumber pembiayaan maka memungkinkan untuk dilakukan program penelitian dan pengembangan. Leverage digunakan sebagai proksi tekanan eksternal di mana leverage yang tinggi akan menimbulkan tekanan pada manajemen sehingga terjadi hubungan positif terhadap kecurangan laporan keuangan.

Ross et al. (dalam Tarjo, 2003) menyatakan bahwa aliran kas bebas (free cash flow) biasanya menimbulkan konflik kepentingan antara pemegang saham dan 
manajer, dimana manajer berkeinginan dana yang ada digunakan untuk investasi pada proyek-proyek yang menguntungkan karena pada masa mendatang akan menambah insentif bagi manajer. Dechow et al. (dalam Skousen et al., 2009) menunjukkan bahwa bila suatu perusahaan memiliki sumber dana internal yang memadai, manajer cenderung untuk terlibat dalam kecurangan pelaporan keuangan. Mengacu pada penelitian Skousen et al. (2009), proksi aliran kas bebas (FREEC) memiliki hubungan positif dengan kecurangan laporan keuangan.

Beasley, COSO, dan Dunn (dalam Skousen et al., 2009) mengindikasi saat eksekutif memiliki porsi kepemilikan di dalam perusahaan, maka situasi keuangan pribadi mereka juga akan dipengaruhi oleh kondisi keuangan perusahaan. Tekanan manajemen untuk memenuhi kebutuhan keuangan pribadinya menjadi faktor pemicu untuk melakukan kecurangan dengan meningkatkan laba perusahaan sehingga porsi dividen yang akan dihasilkan juga cenderung lebih besar. Berdasarkan pernyataan tersebut penelitian ini menggunakan proksi persentase saham perusahaan yang dimiliki manajer (OSHIP) dan persentase manajemen yang memiliki proporsi saham di atas 5\% (5\%OWN) memiliki hubungan positif dengan kecurangan laporan keuangan.

ROA biasanya digunakan sebagai pengukuran untuk kinerja operasi perusahaan yang secara luas untuk mengindikasikan seberapa efisien aset telah digunakan. ROA biasanya dipakai untuk menilai kinerja manajer serta menentukan besarnya bonus yang akan diberikan. Summers dan Sweeney (dalam Skousen et al., 2009) melaporkan bahwa ROA akan menunjukkan perbedaan yang signifikan antara perusahaan yang melakukan kecurangan dengan perusahaan yang tidak melakukan kecurangan, di mana nilai ROA yang dihasilkan perusahaan dengan tindak kecurangan lebih tinggi dibandingkan dengan yang tidak melakukan tindak kecurangan sehingga memiliki hubungan positif dengan kecurangan laporan keuangan.

\section{Kesempatan}

Pada laporan keuangan terdapat akun-akun tertentu yang besarnya saldo ditentukan oleh perusahaan berdasarkan suatu estimasi, misalnya akun piutang tak tertagih dan akun persediaan usang. Kesalahan secara sengaja dalam menentukan estimasi untuk menilai saldo piutang tak tertagih dan menilai saldo persediaan usang menjadi sebuah kesempatan bagi manajemen untuk melakukan kecurangan. Summers dan Sweeney (dalam Skousen et $a l ., 2009)$ menyatakan bahwa manajer akan fokus terhadap kedua akun tersebut jika berniat melakukan manipulasi pada laporan keuangan. Mengacu pada penelitian 
sebelumnya, proksi rasio perubahan piutang pada penjualan selama dua tahun (RECEIVABLE) dan rasio perubahan persediaan pada penjualan selama dua tahun (INVENTORY) akan berpengaruh positif terhadap kecurangan laporan keuangan.

Penelitian

terdahulu

mendokumentasikan hubungan antara independensi anggota komite audit dengan integritas serta kualitas laporan keuangan. Pamudji dan Trihartati (n.d.) membuktikan bahwa perusahaan dengan komite audit yang independen cenderung tidak melakukan kecurangan karena komite audit memiliki fungsi pengawasan untuk menjamin bahwa manajemen melakukan tugasnya dengan baik, sehingga terjadi hubungan negatif antara proksi independensi komite audit (ACINDP) dengan kecurangan laporan keuangan.

\section{Pembentukan dan Pedoman} Pelaksanaan Komite Audit Nomor IX.I.5 menurut BAPEPAM mengenai keanggotaan komite audit merekomendasikan adanya minimal satu anggota komite audit yang memiliki keahlian akuntansi atau keuangan dengan asumsi bahwa anggota tersebut dapat meningkatkan keefektifan kinerja. Ahli finansial dengan pengetahuan dan keahlian tertentu, diharapkan mereka dapat memandu anggota komite audit lainnya untuk mengidentifikasi pertanyaan yang dapat memberi tantangan pada manajemen dan audit eksternal, serta dapat meningkatkan kualitas laporan keuangan sehingga akan terjadi hubungan negatif antara proksi keahlian keuangan yang dimiliki komite audit (ACEXP) dengan kecurangan laporan keuangan.

Berdasarkan Surat Edaran dari Direksi PT. Bursa Efek Jakarta No. SE008/BEJ/12-2001 tanggal 7 Desember 2001 serta Pembentukan dan Pedoman Pelaksanaan Komite Audit Nomor IX.I.5 menurut BAPEPAM mengenai keanggotaan komite audit, disebutkan bahwa jumlah anggota komite audit minimal tiga orang, termasuk ketua komite audit. Semakin banyak jumlah anggota akan semakin meningkatkan efektivitas pengawasan sehingga manajemen tidak memiliki kesempatan untuk melakukan kecurangan. Berdasarkan uraian di atas maka proksi jumlah anggota komite audit (ACSIZE) berpengaruh negatif pada kecurangan laporan keuangan.

Peraturan Nomor IX.I.5 mengenai Pembentukan dan Pedoman Pelaksanaan Komite Audit oleh BAPEPAM menyatakan bahwa komite audit wajib mengadakan rapat secara berkala minimal sekali dalam tiga bulan, yang artinya dalam setahun komite audit harus mengadakan pertemuan minimal empat kali. Semakin banyak pertemuan yang dilakukan oleh para komite audit maka akan semakin efektif pula pengawasan yang dilakukan, sehingga kesempatan untuk melakukan kecurangan bisa diminimalisir. 
Abbot et al. (dalam Ika dan Ghazali, 2012) membuktikan perusahaan dengan komite audit yang mengadakan pertemuan minimal empat kali dalam setahun cenderung tidak melakukan re-statement laporan keuangan sehingga akan terjadi hubungan yang negatif antara jumlah rapat tahunan komite audit dengan kecurangan laporan keuangan (ACMEET).

Kompleksitas dan ketidakstabilan struktur organisasi perusahaan ditandai dengan tingginya perputaran posisi manajer senior, konsultan, dan jajaran direksi (Skousen et al., 2009). Adanya pergantian struktur jajaran direksi biasanya diikuti dengan praktek manajemen laba karena mendekati masa akhir jabatannya manajemen akan memaksimalkan bonus akhir tahun (Rama, n.d.). Manajemen laba juga bisa dilakukan saat manajemen tidak bisa mencapai target perusahaan yang berdampak pada pergeseran jabatan. Mengacu pada penelitian sebelumnya digunakan proksi jumlah direksi yang meninggalkan perusahaan selama dua tahun (TURN) yang memiliki hubungan positif dengan kecurangan laporan keuangan.

\section{Rasionalisasi}

Beberapa penelitian mengindikasi bahwa insiden kegagalan audit meningkat saat terjadi pergantian auditor dalam perusahaan (Skousen et al., 2009). Hal ini disebabkan karena auditor independen yang baru masih belum mengerti kondisi perusahaan secara keseluruhan di samping itu jangka waktu proses audit yang terbatas menjadi kendala dalam proses audit untuk mendeteksi adanya kecurangan tersembunyi. Penelitian ini akan menggunakan proksi perubahan auditor independen (AUDCHANGE) yang berpengaruh positif terhadap kecurangan laporan keuangan.

Francis and Krishnan (dalam Skousen et al., 2009) menyimpulkan bahwa kelebihan dari penggunaan diskresionari akrual menyebabkan opini audit tidak wajar. Tindakan manajemen laba tersebut tentunya karena manajemen merasionalkan perbuatannya. Proksi AUDREPORT digunakan untuk mengukur rasionalisasi yang memiliki pengaruh negatif terhadap kecurangan laporan keuangan.

\section{Populasi dan Sampel Penelitian}

Populasi dalam penelitian ini adalah perusahaan non-keuangan yang terdaftar di Bursa Efek Indonesia antara tahun 2008 sampai 2012. Sampel pada penelitian ini diambil dengan metode purposive sampling, yaitu penentuan sampel atas dasar kesesuaian karakteristik dan kriteria tertentu. Kriteria pemilihan sampel pada penelitian ini adalah sebagai berikut:

1. Sampel merupakan perusahaan sektor non-keuangan yang melakukan kecurangan menurut laporan sanksi yang dikeluarkan oleh Otoritas Jasa Keuangan 
(OJK). Kriteria ini dikarenakan terdapat perbedaan karakteristik antara perusahaan pada sektor non-keuangan dengan perusahaan sektor keuangan dalam pelaporan keuangan. Selanjutnya dilakukan pemadanan sampel (paired matching) dengan sampel merupakan perusahaan sektor non-keuangan yang tidak melakukan kecurangan dan sahamnya diperdagangkan di Bursa Efek Indonesia. Pemadanan perusahaan nonkecurangan berdasarkan nilai total aset perusahaan dan jenis industri.

2. Perusahaan memiliki data terkait penelitian ini seperti akun-akun tertentu untuk memenuhi rasio keuangan yang dijadikan sebagai proksi variabel independen.

\section{Metode Analisis}

Metode regresi logistik digunakan untuk melihat hubungan perusahaan yang melakukan kecurangan laporan keuangan dengan teori fraud triangle. Variabel dependen yang digunakan merupakan variable binary, yaitu apakah perusahaan melakukan kecurangan atau tidak. Variabel independen yang digunakan dalam model ini adalah tekanan, kesempatan, dan rasionalisasi yang diproksikan ke dalam beberapa kategori. Persamaan yang dibentuk dengan menggunakan regresi logistik adalah sebagai

berikut:

Ln $(\mathrm{F} / 1-\mathrm{F})=\beta_{0}+\beta_{1} \mathrm{GPM}+\beta_{2} \mathrm{NPM}+\beta_{3} \mathrm{SCHANGE}+\beta_{4}$ ACHANGE $+\beta_{5}$ CATA $+\beta_{6}$ SALAR $+\beta_{7}$ SALTA $+\beta_{8}$ INVSAL $+\beta_{9}$ HIGHGR $+\beta_{10}$ LOSS $+\beta_{11} \mathrm{NCFO}+\beta_{12}$ LEV $+\beta_{13}$ FREEC $+\beta_{14}$ OSHIP $+\beta_{15} 5 \%$ OWN $+\beta_{16}$ ROA $+\beta_{17}$ RECEIVE $+\beta_{18}$ INVENT $+\beta_{19}$ ACMEET $+\beta_{20}$ ACINDP $+\beta_{21}$ ACEXP $+\beta_{22}$ ACSIZE $+\beta_{23}$ TURN $+\beta_{24}$ AUREPORT + $\beta_{25}$ AUCHANGE + e

Keterangan:

Ln (F/1-F) : dummy variabel dimana 1 untuk perusahaan yang melakukan kecurangan, 0 jika sebaliknya

$\beta_{0} \quad$ : konstanta

GPM : gross profit margin

NPM : net profit margin
SCHANGE : perbandingan perubahan penjualan perusahaan dengan industri

ACHANGE : persentase perubahan aset selama 2 tahun sebelum kecurangan

CATA : rasio arus kas operasi terhadap aset

SALAR : penjualan/piutang dagang

SALTA : penjualan/total aset 


$\begin{array}{ll}\text { INVSAL } & \text { : persediaan/total aset } \\ \text { HIGHGR } & : 1 \text { jika tingkat pertumbuhan } \\ & \text { aset perusahaan lebih besar } \\ & \text { dari pertumbuhan industri, } 0 \\ & \text { jika sebaliknya } \\ \text { LOSS } & : \quad 1 \text { jika perusahaan } \\ & \text { mengalami kerugian selama } \\ & 2 \text { tahun sebelum } \\ & \text { kecurangan, } \\ & \text { sebaliknya }\end{array}$

NCFO $\quad 1$ jika perusahaan arus kas operasi negatif selama 2 tahun sebelum kecurangan, 0 jika sebaliknya

LEV : rasio leverage

FREEC : arus kas bersih operasi dikurangi dividen dan belanja modal

$\begin{array}{ll}\text { OSHIP } & : \text { komposisi saham yang } \\ & \text { dimiliki manajemen } \\ 5 \% \text { OWN } & : \text { komposisi saham diatas } 5 \% \\ & \text { yang dimiiliki manajemen } \\ \text { ROA } & : \text { rasio return on asset } \\ \text { RECEIV } & : \quad\left(\text { piutang }_{t} / \text { penjualan }_{\mathrm{t}}\right) \quad- \\ & \quad\left(\text { piutang }_{\mathrm{t}-1} / \text { penjualan }_{\mathrm{t}-1}\right)\end{array}$

INVENT : (persediaan/penjualan $\left.{ }_{\mathrm{t}}\right)_{-}$ (persediaan $-1 /$ penjualan $_{\mathrm{t}-1}$ )

ACINDP $: 1$ jika seluruh anggota komite audit berasal dari luar, 0 jika sebaliknya

ACEXP $: 1$ jika satu anggota komite audit memiliki keahlian keuangan, 0 jika sebaliknya
ACSIZE $\quad 1$ jika komite audit berjumlah 3 orang atau lebih, 0 jika sebaliknya

ACMEET : 1 jika pertemuan komite audit minimal 4 kali setahun,0 jika sebaliknya

TURN : jumlah direksi meninggalkan perusahaan selama 2 tahun sebelum kecurangan

AUDCHANGE : 1 jika terjadi perubahan auditor selama 2 tahun sebelum kecurangan, 0 jika sebaliknya

AUDREPORT : 1 jika opini wajar selama 2 tahun sebelum kecurangan, 0 jika sebaliknya

e : disturbance eror

\section{HASIL PENELITIAN DAN}

PEMBAHASAN

\section{Analisis Univariate dengan Uji Mann-}

Whitney

Berdasar prosedur pengujian Skousen et al. (2009) maka sebelum dilakukan pengujian hipotesis dengan analisis multivariat maka dilakukan analisis univariat dengan uji Mann-Whitney. Uji ini dilakukan untuk mengetahui proksi variabel independen yang dapat membedakan secara signifikan antara perusahaan yang melakukan kecurangan laporan keuangan dan perusahaan yang tidak melakukan 
kecurangan. Proksi yang memiliki nilai signifikansi kurang dari 0,05 menandakan bahwa proksi tersebut mampu membedakan kategori pada variabel dependen sehingga proksi tersebut yang selanjutnya akan digunakan pada analisis regresi logistik.
Penggunaan uji Mann-Whitney ini mengacu pada penelitian sebelumnya yang dilakukan oleh Skousen et al. (2009). Berikut hasil uji Mann-Whitney:

Tabel 1.2

Hasil Uji Mann-Whitney

\begin{tabular}{lclc}
\hline \multicolumn{1}{c}{ b } & $\begin{array}{c}\text { Mann-Whitney } \\
\text { Sig. }\end{array}$ & \multicolumn{1}{c}{ Proksi } & $\begin{array}{c}\text { Mann-Whitney } \\
\text { Sig. }\end{array}$ \\
\hline GPM & 0,411 & OSHIP & 0,316 \\
NPM & 0,005 & FREEC & 0,392 \\
SCHANGE & 0,749 & OWN & 0,153 \\
ACHANGE & 0,154 & ROA & 0,004 \\
CATA & 0,551 & RECEIV & 1,000 \\
SALAR & 0,364 & INVENT & 0,545 \\
SALTA & 0,002 & ACEXP & 0,045 \\
INVSAL & 0,058 & ACSIZE & 0,556 \\
LOSS & 0,278 & ACMEET & 0,488 \\
NCFO & 0,005 & TURN & 0,735 \\
LEV & 0,539 & AUDCHANGE & 0,738 \\
\hline
\end{tabular}

Pada tabel uji Mann-Whitney pemilihan proksi yang akan digunakan pada analisis regresi logistik adalah proksi yang memiliki nilai signifikansi kurang dari 0,05. Berdasarkan tabel di atas maka proksi yang dipilih adalan net profit margin (NPM), sales to total asset (SALTA), negative cash flow (NCFO), return on asset (ROA), dan audit committee expertise (ACEXP). Selanjutnya penelitian ini akan menyajikan analisis logistik regresi dengan persamaan yang sudah dikurangi yaitu hanya terdiri dari variabel eksplanatori dari hasil uji MannWhitney. Berikut persamaan regresi logistik yang akan dipakai:
$\operatorname{Ln}(\mathrm{F} / 1-\mathrm{F})=\beta_{0}+\beta_{1} \mathrm{NPM}+\beta_{2} \mathrm{SALTA}+\beta_{3}$

$\mathrm{NCFO}+\beta_{4} \mathrm{ROA}+\beta_{5} \mathrm{ACEXP}+\mathrm{e}$

\section{Uji Hipotesis}

Pengujian hipotesis dalam penelitian ini akan dilakukan dengan menggunakan model regresi logistik. Penggunaan model regresi logistik karena variabel dependen (kecurangan laporan keuangan) merupakan data non-metrik, dimana kode 1 jika perusahaan melakukan kecurangan laporan keuangan dan 0 jika perusahaan tidak melakukan kecurangan laporan keuangan. Setelah mendapatkan model regresi logistik yang fit yang tidak memerlukan modifikasi model, maka pengujian hipotesis dapat 
dilakukan. Hasil pengujian hipotesis parsial. Berikut hasil uji regresi logistik: dilakukan dengan menggunakan uji secara

Tabel 1.3

Hasil Uji Regresi Logistik

\begin{tabular}{clrrrr}
\hline Hipotesis & Proksi & \multicolumn{1}{c}{ B } & \multicolumn{1}{c}{ S.E. } & Wald & \multicolumn{1}{c}{ Sig. } \\
\hline & NPM & -1.091 & 1.124 & 0.942 & 0.332 \\
H 1 & SALTA & -1.391 & 0.679 & 4.196 & 0.041 \\
(Tekanan) & NCFO & 2.445 & 1.281 & 3.642 & 0.056 \\
& ROA & -17.927 & 12.899 & 1.932 & 0.165 \\
H 2 & ACEXP & -2.684 & 1.363 & 3.880 & 0.049 \\
(Kesempatan) & Constant & 3.412 & 1.583 & 4.645 & 0.031 \\
\hline
\end{tabular}

\section{Pengaruh Rasio Margin Laba Bersih \\ Terhadap Kecurangan Laporan}

\section{Keuangan}

Berdasarkan pengujian hipotesis menunjukkan bahwa untuk variabel tekanan dengan proksi marjin laba bersih (NPM) terhadap probabilitas suatu perusahaan melakukan tindakan kecurangan laporan keuangan diperoleh koefisien negatif sebesar 1,091 dengan signifikansi sebesar 0,332. Nilai signifikansi yang lebih besar dari 0,05 menunjukkan bahwa NPM tidak memiliki pengaruh signifikan terhadap probabilitas suatu perusahaan melakukan tindakan kecurangan laporan keuangan sehingga dapat disimpulkan bahwa marjin laba bersih bukan sebagai faktor risiko kecurangan.

\section{Pengaruh Rasio Perputaran Aset}

\section{Terhadap Kecurangan Laporan}

\section{Keuangan}

Berdasarkan pengujian hipotesis menunjukkan bahwa untuk variabel tekanan dengan proksi penjualan dibagi total aset (SALTA) terhadap probabilitas suatu perusahaan melakukan tindakan kecurangan laporan keuangan diperoleh koefisien negatif sebesar 1,391 dengan signifikansi sebesar 0,041. Nilai signifikansi yang lebih kecil daripada 0,05 menunjukkan bahwa SALTA memiliki pengaruh signifikan terhadap probabilitas suatu perusahaan melakukan tindakan kecurangan laporan keuangan. Berdasarkan hasil penelitian dapat disimpulkan bahwa nilai SALTA yang semakin besar mencerminkan bahwa perusahaan dapat menggunakan asetnya secara baik sehingga tindak kecurangan tidak terjadi.

Penelitian ini bertentangan dengan hasil yang didapat oleh Skousen et al. (2009) namun konsisten dengan penelitian yang dilakukan Persons (1995) bahwa ketidakmampuan dalam penggunaan aset perusahaan memberikan motivasi bagi manajer untuk terlibat dalam kecurangan 
pelaporan keuangan. Hasil yang sama juga ditunjukkan pada penelitian Prajanto (2012).

\section{Pengaruh Adanya Arus Kas Operasi} Negatif Terhadap Kecurangan Laporan

\section{Keuangan}

Berdasarkan pengujian hipotesis menunjukkan bahwa untuk variabel tekanan dengan proksi arus kas operasi negatif (NCFO) terhadap probabilitas suatu perusahaan melakukan tindakan kecurangan laporan keuangan diperoleh koefisien positif sebesar 2,445 dengan signifikansi sebesar 0,056 . Nilai signifikansi yang lebih besar daripada 0,05 menunjukkan bahwa NCFO tidak memiliki pengaruh signifikan terhadap probabilitas suatu perusahaan melakukan tindakan kecurangan laporan keuangan. Berdasarkan hasil penelitian ini dapat disimpulkan bahwa NCFO bukan sebagai faktor risiko kecurangan. Hasil penelitian ini konsisten dengan penelitian yang dilakukan oleh Lou dan Wang (2009) yang tidak berhasil membuktikan keterkaitan antara proksi NCFO dengan kecurangan laporan keuangan.

\section{Pengaruh Rasio ROA Terhadap}

\section{Kecurangan Laporan Keuangan}

Berdasarkan pengujian hipotesis menunjukkan bahwa untuk variabel tekanan dengan proksi return on asset (ROA) terhadap probabilitas suatu perusahaan melakukan tindakan kecurangan laporan keuangan diperoleh koefisien negatif sebesar 17,927 dengan signifikansi sebesar 0,165. Nilai signifikansi yang lebih besar dari 0,10 menunjukkan bahwa ROA tidak memiliki pengaruh signifikan terhadap probabilitas suatu perusahaan melakukan tindakan kecurangan laporan keuangan.

Hal ini karena ROA digunakan untuk tujuan jangka pendek padahal manajer juga harus memikirkan program jangka panjang agar dapat meningkatkan keuntungan perusahaan secara keseluruhan (Hutomo, 2012). Penelitian ini konsisten dengan hasil penelitian Skousen et al. (2009) yang menyatakan bahwa ROA bukanlah sebagai faktor risiko tekanan dalam mengidentifikasi kemungkinan tindak kecurangan pelaporan keuangan.

Berdasarkan hasil interpretasi untuk variabel tekanan, dari seluruh proksi yang diuji hanya didapat empat proksi yang lolos uji Mann-Whitney. Keempat proksi tersebut kemudian dilakukan uji hipotesis menggunakan uji regresi logistik dan didapat satu proksi yang signifikan pada nilai 0,05 yaitu proksi rasio perputaran aset (SALTA). Berdasarkan hasil uji hipotesis dapat disimpulkan bahwa variabel tekanan berpengaruh terhadap probabilitas perusahaan melakukan kecurangan laporan keuangan yang diproksikan dengan SALTA sehingga $\mathrm{H} 1$ didukung. 
Pengaruh Keahlian Keuangan yang

dimiliki Komite Audit Terhadap

\section{Kecurangan Laporan Keuangan}

Berdasarkan pengujian hipotesis menunjukkan bahwa untuk variabel kesempatan dengan proksi keahlian keuangan komite audit (ACEXP) terhadap probabilitas suatu perusahaan melakukan tindakan kecurangan laporan keuangan diperoleh koefisien negatif sebesar 2,684 dengan signifikansi sebesar 0,049. Nilai signifikansi yang lebih kecil dari 0,05 menunjukkan bahwa ACEXP memiliki pengaruh signifikan terhadap probabilitas suatu perusahaan melakukan tindakan kecurangan laporan keuangan. Adanya ahli keuangan atau akuntansi dalam keanggotaan komite audit dapat meningkatkan pengawasan terhadap manajemen. Komite audit yang bertugas mengawasi serta memeriksa laporan keuangan yang dibuat oleh manajemen maka dengan adanya ahli keuangan dalam keanggotaan komite audit diharapkan dapat menjamin kebenaran laporan keuangan yang nantinya akan diberikan kepada dewan komisaris. Hasil penelitian ini konsisten dengan penelitian yang dilakukan oleh Prasetyo (2012).

\section{KESIMPULAN}

Penelitian ini bertujuan untuk menguji faktor-faktor yang mempengaruhi suatu perusahaan melakukan kecurangan laporan keuangan dengan menggunakan pendekatan teori fraud triangle. Berdasarkan hasil uji yang telah dilakukan maka dapat disimpulkan bahwa hasil uji Man-Whitney tidak semua proksi mampu membedakan nilai rata-rata sampel perusahaan yang melakukan kecurangan dan yang tidak melakukan kecurangan. Proksi yang memiliki perbedaan yang signifikan adalah net profit margin (NPM), sales to total asset (SALTA), arus kas operasi negatif (NCFO), return on asset (ROA), dan keahlian keuangan komite audit (ACEXP).

Berdasarkan hasil uji logistik regresi didapat proksi SALTA yang berpengaruh negatif dan signifikan terhadap kecurangan laporan keuangan. Adanya ahli keuangan dalam keanggotaan komite audit (ACEXP) merupakan proksi yang dipakai untuk menggambarkan variabel kesempatan. Hasil uji logistik regresi menunjukkan adanya hubungan negatif antara keahlian keuangan yang dimiliki komite audit dengan kecurangan laporan keuangan. Penelitian ini belum dapat memberikan bukti empiris keterkaitan antara variabel rasionalisasi dengan kecurangan laporan keuangan.

Penelitian ini memiliki beberapa keterbatasan. Pertama, pemilihan proksi dalam penelitian ini mungkin kurang mampu untuk mendeteksi adanya kecurangan laporan keuangan. Kedua, hipotesis 3 tidak dapat diuji dengan analisis regresi logistik karena proksi yang 
digunakan tidak lolos uji Mann-Whitney. Hal ini disebabkan karena pemilihan proksi untuk variabel rasionalisasi kurang mampu untuk mendeteksi adanya kecurangan laporan keuangan.

Atas dasar keterbatasan tersebut maka diharapkan penelitian selanjutnya untuk mengembangkan proksi untuk variabel tekanan, kesempatan, dan rasionalisasi yang lebih mampu untuk mendeteksi adanya kecurangan laporan keuangan sesuai dengan kondisi perekonomian Indonesia. Terutama untuk proksi rasionalisasi perlu diperhatikan karena dalam penelitian ini tidak mampu untuk menunjukkan adanya signifikansi. Selain itu, menggunakan objek penelitian yang lebih luas dengan memperpanjang tahun penelitian sehingga jumlah sampel yang digunakan dalam penelitian akan lebih besar. Mengingat jumlah terjadinya kecurangan laporan keuangan hanya kisaran $5 \%$ dari total kecurangan yang terjadi di perekonomian.

\section{DAFTAR PUSTAKA}

Albrecht, C., C. Turnbull, Y. Zang, and C.J. Skousen. 2010. The relationship Between South Korean Chaebols and Fraud. "Management Research Review, Vol. 33, No. 3, h. 257-268

Cressey, D. (1953). Other people's money, dalam: "Detecting and Predicting Financial Statement Fraud: The Effectiveness of The Fraud Triangle and SAS No. 99, Skousen et al. 2009. Journal of Corporate Governance and Firm Performance. Vol. 13 h. 53-81

Djankov, S. La Porta, R. Lopez-de-Silanes, F dan Shleifer, A. 2008. The Law and Economics of Self-dealing. Journal of Financial Economics. Vol. 88. Hal: 430 - 465

Gagola, Antonius S.C. 2011. "Analisis Faktor Risiko Yang Mempengaruhi Kecenderungan Kecurangan Pelaporan Keuangan Perusahaan Publik Di Indonesia". Tesis Tidak Dipublikasikan, Program Studi Magister Akuntansi program Pasca sarjana, Universitas Diponegoro

Hutomo, O.S. 2012. "Cara Mendeteksi Fraudulent Financial Reporting dengan Menggunakan Rasio-Rasio Finansial." Skripsi Tidak Dipublikasikan, Fakultas Ekonomika dan Bisnis, Universitas Diponegoro

\section{http://www.idx.co.id}

IAPI, 2013, Standar Profesional Akuntan Publik, Pernyataan Standar Audit 70: Pertimbangan atas Kecurangan dalam Audit Laporan Keuangan

Ika, S.R dan Nazli A.M. Ghazali. 2012 "Audit Committee Effectiveness And Timeliness of Reporting: Indonesian evidence." Managerial Auditing Journal, Vol. 27 No. 4 pp. 403-424

Jensen, M.C. dan W.H. Meckling. 1976. "Theory of The Firm: Managerial Behaviour, Agency Cost, and Ownership Structure", Journal of Financial Economics, Vol. 3, No. 4, h. $305-360$

Leuz, C. Nanda, D. dan Wysocki. 2003. Earning Management and Investor Protection: An International 
Comparison. Journal of Financial Economics. Vol. 69. Hal: 505 - 527

Lou, Y.I. and Ming-Long Wang. 2009. Fraud Risk Factor Of The Fraud Triangle Assessing The Likelihood Of Fraudulent Financial Reporting. "Journal of Business \& Economics Research, Vol. 7, no. 2, h. 61-78

Pamudji, S., dan A. Trihartati. n.d. Pengaruh Independensi Dan Efektifitas Komite Audit Terhadap Manajemen Laba (Studi Empiris Pada Perusahaan Manufaktur Yang Terdaftar Di Bei). Artikel Tidak Dipublikasikan. Fakultas Ekonomi Universitas Diponegoro

Persons, O. 1995. Using financial statement data to identify factors associated with fraudulent financial reporting. Journal of Applied Business Research. Vol. 11, No. 3. Hal: 38-46.

Prajanto, Agung. 2012. "Pengaruh Rasio Keuangan dan Budaya Perusahaan terhadap Kecurangan Pelaporan Keuangan". Tesis Tidak Dipublikasikan, Program Studi Magister Akuntansi program Pasca sarjana, Universitas Diponegoro

Prasetyo, A.B. 2012. "Pengaruh Karakteristik Komite Audit dan Perusahaan terhadap Kecurangan Pelaporan Keuangan." Tesis Tidak Dipublikasikan, Program Studi Magister Akuntansi program Pasca sarjana, Universitas Diponegoro

Rama, Radian Sri. n.d. "Manajemen Laba (earning management) Dalam Perspektif Etika Hedonism. " Jurnal Akuntansi dan Auditing Indonesia, Vol. 7, No. 2, h. 183-208

Rustendi, Tedi. 2009. Analisis Terhadap Faktor Pemicu Terjadinya Fraud (Suatu Kajian Teoritis Bagi
Kepentingan Audit Internal). "Jurnal Akuntansi, Vol. 4, No. 2, h. 705-714

Skousen, C.J., K.R. Smith, dan C.J. Wright. 2009. Detecting and Predicting Financial Statement Fraud : The Effectiveness of The Fraud Triangle and SAS no. 99. "Journal of Corporate Governance and Firm Performances, Vol 13, h. 53-81

Tarjo. 2003. "Analisis Free Cash Flow dan Kepemilikan Managerial terhadap Kebijakan Hutang pada Perusahaan Publik di Indonesia." Artikel yang dipresentasikan pada Simposium Nasional Akuntansi VI, Surabaya, 16-17 Oktober 2003 